\title{
Research on Resource Integration and Utilization Strategies of School-Enterprise in Linyi
}

\author{
Mei Zhang * \\ Library, Linyi University, Shandong, 276000, China \\ Zhangmei7596@163.com
}

Keywords: School-enterprise cooperation; School-enterprise resource; Integration and utilization; Integration mode.

\begin{abstract}
With the rapid development of higher education and vocational education, the problems and strategies of school-enterprise cooperation and resource integration were studied to train the workers meeting the society needs. Taking Linyi of China as an example, the school-enterprise cooperation and the main modes of resource integration were introduced, and the integration problems were focused on from the aspects of government, colleges and enterprises. Combined with the actual situation of Linyi economic development, the suggestions and strategies of Linyi school-enterprise resource integration were put forward. The study was hoped to promote deeper cooperation with colleges and enterprises in higher education and vocational education.
\end{abstract}

\section{Introduction}

In order to adapt to the rapid development of economy needs, our educational field, especially higher education and vocational education are fully joining to society, getting to know business and forming a good cooperative relationship. In the aspects of school-enterprise cooperation and resource integration, we carried out exploration of different forms, different levels and different characteristics. Compared with developed countries, there is a gap in the integration of depth, level and mode.

Linyi, located in the southeast of Shandong Province, is the largest and most populous prefecture-level city. In the past two decades, Linyi has become an emerging modern business logistics city, manufacturing rapidly rose, and emerged a number of star enterprise, such as Shandong Lingong, Shandong Changlin, Yuantong automobile trade group. The enterprises require a large number of talents, especially high-end management and design talents.

With the rapid development of economy, the education of Linyi has also ushered in leaping development. The major colleges include Linyi University, Shandong Medical College, Linyi Technician College, Lin Vocational College and Shandong Transportation Technology Colleges. Compared with economic development, the high education of Linyi is relatively backward and the number and level is low, which can not meet the needs of personnel training.

It has become the inevitable choice for colleges and enterprises to conduct school-enterprise cooperation. Based on the experience of the developed countries, we put forward countermeasures and suggestions, effectively promote Linyi school-enterprise cooperation and deepen the integration and utilization level of resources, to make universities and enterprises benefit.

\section{Main Mode of Integration and Utilization of Resources in Linyi}

Practice Base Mode. Practice teaching is the core of students engineering ability, but the university practice teaching mainly rely on the lab. Due to the restrictions of space, funds and teachers, it affects students engineering ability, so school-enterprise sharing and building practice base together are the most common model.

In the practice base model, students learn theoretical knowledge in the first two or three years, and post practice in the last year. Universities are responsible for student training, companies do not participate in the personnel training programs, only provide practical internship positions, and help 
students to be familiar with the work environment and job requirements. Such mode achieves the school-enterprise integration, but it is a low-level integration, cooperation is short-term, and the number of students accepted by companies is subject to seasons and cycles [1].

Order Training Mode. In the order training mode, institutions signed the agreement with companies. According to teaching programs and job competency requirements, both sides jointly develop training objectives, graduation examination and graduation reception. In the mode, the students directly enter the enterprise after graduation, which shorten the adjustment period, avoid talent blind and save human resource costs. Order training mode integrates human, material and information of school-enterprise, and exist as title class [2].

For example, the mechanical engineering school of Linyi university cooperates with Shandong Changlin Machinery Group Co., Ltd., Shandong Huashengzhongtian Machinery Group Co., Ltd. and other enterprises, and starts Changlin Class, Huashengzhongtian Class, enrolls students from sophomore, jointly train special talent for enterprise making full use of school-enterprise resources.

Refresher Training Mode. In the refresher training mode, the colleges have become the training base for enterprise employees. According to the enterprise development plans and talent demand, colleges develop training programs, achieve training goal and post requirements in synchronization, school teaching content and production task in synchronization and educational mission for local economic development services. In the refresher training mode, the enterprise do not need to recruit new employees. The colleges retrain the existing staff to adapt to technological advances and new demands, enhance the stability of employees, increase the curiosity of employees, and promote the sustainable development of enterprises and workers [3].

School-run Enterprise Mode. In the school-run enterprise mode, universities set up new businesses independently or in cooperation with business using training equipment and professional teachers. School-run enterprises can not only meet the needs of student internship training, but also transform technology and business theoretical results, which is the practice teaching base with the integration of teaching, production and scientific research [4]. School-run enterprise mode integrates school-enterprise resources in all aspects, but it also has problems, such as difficult to founder and manage and business risk.

Business School Mode. In the business school mode, enterprises actively invest in colleges, become the main organizer of school-enterprise cooperation, and participate in personnel training fully. For enterprises, they can get professional talent pool, and for colleges, they only responsible for the recruitment and professional basic courses, for students, they not only learn the latest technology, but also directly employ [5].

For example, Linyi vocational college decided to cooperate with Shandong Chenshi Construction Engineering Group after the negotiation, and established Yinan campus of Linyi Vocational College. This mode makes colleges and students be close to the business and market, makes companies have a sustainable manpower source, and companies actively involve in the construction of teaching staff and training facilities. Students are entitled to free school places, paid internship and get jobs.

Technical Service Model. In the technical service mode, colleges use academic strengths and experimental facilities to overcome technical difficulties for new technologies and new products, or to establish public service platform for the industry, and provide professional technical development and services. This mode is applied to colleges with strong technical research, advanced scientific instruments, high-quality personnel and strong sense of service.

\section{Problems Existing of School-enterprise Resource Integration in Linyi}

From the analysis of school-enterprise resource integration mode, it can be seen that Linyi school-enterprise cooperation have made great achievement, ideas constantly updated and pattern varied. However, Linyi school-enterprise resource integration is still in low level and extensive stage. 
By the investigation of 10 colleges and 50 companies in Linyi, the major factors in the integration were drawn. Table 1 lists the causes from different angles.

Table 1 The main factors affecting school-enterprise cooperation and resource integration
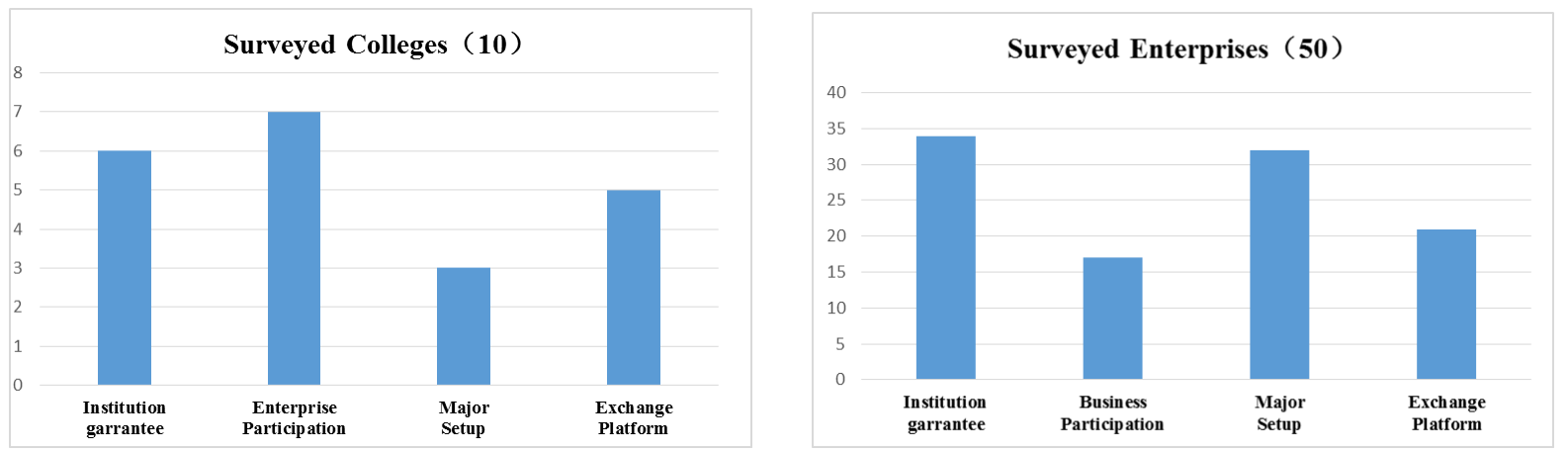

Lack of Government Support and System Security. School-enterprise resource integration is not only the cooperation of colleges and enterprises, teaching and production, but also the cooperation of technology and economy, therefore, there should be appropriate policies and regulations to regulate and promote, and provide the necessary funding [6].

Compared with developed countries and economically developed regions, due to relatively tight fiscal of Linyi, the local government took less notice to the school-enterprises cooperation and resource integration, and lack enthusiasm of developing relevant policies. It is an urgent problem to improve relevant policies and regulations, seek funding support, and get the attention and support of government.

Regional Economy Underdeveloped and Lack of Long-term Business Plan. On the whole, Linyi is an underdeveloped region, and the number of scale enterprise is small. The enterprises only want to employ but not train persons, lack of participation sense and responsibility of personnel training. Some enterprises remain at the low end of industrial chain, less demanding on staff skills. Some enterprises have weak market competitiveness, less money, and are unwilling or unable to invest in staff training. Therefore, there is less school-enterprise demand for the enterprises of Linyi, enthusiasm is not high, the level of cooperation shallow, most are confined to student internships and employment, and less rise to the common development and education plan level.

Specialty Arrangement is Stale and Disconnected from Society. The level of Linyi high education is low, the number is small and the quality is low, which not match the large city population. There are also problems in the number, quality and structure, especially the poor quality lead to overall graduate students level unsatisfactory, which is difficult to meet the business needs. Moreover, the specialty arrangement of some institutions is incompatible with Linyi industry demand.

Lack of Communication Platforms and Integration Mode Is Old. Colleges and businesses have different demands, the businesses pursuit profits and colleges pursuit talent quality. The biggest problem is lack of communication, bridge link, cooperation platform and carrier between colleges and businesses, or lack of trust in the cooperation, which will restrict the school-enterprise resource integration smoothly [7].

\section{Utilization Strategy of Linyi School-enterprise Resource Integration}

Learning from foreign advanced experience, combined with the economic development situation in Linyi, we put forward the following suggestions to build resource integration mode of win-win cooperation for the colleges and enterprises.

Improve Government Functions and Perfect the Regulatory. It is the key to develop a common awareness of the whole society, for the high vocational education, so colleges and enterprises must actively explore, scientifically build and form the integration, development and Utilization. In this 
regard, the government should play an important guiding role, strengthen the correct propaganda and promote school-enterprise cooperation [8].

Complete legal and institutional safeguards are the prerequisite for high education development in developed countries. Government can develop specific school-enterprise cooperation system and clearly define the rights and obligations of both parties to ensure the smooth integration of school-enterprise resource.

Strictly Control and Implement Employment Permit System. In addition to the industry driving, the development of high vocational education must be restricted by the labor market, namely employment permit system. The government and enterprises should strictly enforce qualification review before posts, strengthen the guidance and employment services, and broaden the employment channels of graduates [9].

Implementation of employment permit system can promote the improvement of talent training quality, and can also effectively regulate the labor market, and more importantly, can promote the school-enterprise cooperation.

Colleges Strengthen the Connotation Construction and Improve the Professional Competence. Professional development is the key whether college personnel training can adapt to social needs. Only open the specialty adapting to market demand, it is possible to win the favor of the enterprise, which requires colleges to carry out market demand analysis, predict talent demand, adjust the structure of talent training and avoid disconnection of education and social needs. So colleges should set the specialty according to market demand, design courses according to post ability, train skill according to the task and implement evaluation according to post standard. Professional and curriculum construction can not only to meet the current needs of economic development, but also take into account the long-term social development, and improve the professional quality and employ ability of graduates [10].

Enterprises Update Ideas and Actively Participate in School-enterprise Resource Integration. The enterprise is the direct beneficiary of educational development, so school-enterprise cooperation is the only way for colleges and businesses to seek common development. So government, colleges and the media should strengthen publicity to make enterprises renew ideas, actively carry out substantive cooperation with colleges, integrate resources and achieve the maximum benefits [11].

Play the Respective Advantages and Explore New Ways to Integrate Resources. Mutual benefit, mutual support and promote is the foundation of successful cooperation between colleges and enterprises. Governments, colleges and businesses should choose a good starting point and seek appropriate cooperation forms. Colleges are think tanks focus on developing professionals, companies are producers demanding labor and governments are policy leaders improving legal systems.

Government can establish Industry Education Steering Committee, absorb experts from administration departments, industry associations, colleges and businesses, to participate in the research and decision-making of related problems, predict industry talent demand, put forward reasonable education and training plan, propose basic requirements for student training objectives, professional standards and teaching reform, and actively promote education reform [12].

Government can set up a special agency to coordinate with both colleges and enterprises, reduce cooperation delays or stranded caused by the information asymmetry, build school-enterprise collaboration platform, guarantee the smooth flow of information and promote the healthy and orderly development of the school-enterprise cooperation.

\section{Conclusions}

In short, by in-depth cooperation between colleges and enterprises, enterprises can select outstanding graduates from college graduates, to enrich the workforce, and colleges become the repository of enterprise talent, while colleges can understand enterprise need for talent conditions, so as to modify personnel training programs. Due to the participation of enterprises, it highlights student professional 
skill training and quality improvement, train good professional ethics and competence, strengthen employment philosophy, achieve zero distance connection of professional skills training and job requirements, and full linking of personnel training and social market demand to realize school-enterprise win-win.

\section{Acknowledgements}

This work was supported by the Teaching Research Project of Young Teachers of Shandong, China (No. 15SDJ014), the Teaching Reform Project of Linyi University in 2014, and the Teaching Quality Engineering Project of Linyi University in 2014.

\section{References}

[1] J. Wang, L.B. Xu, Study on Bidirectional Flow Ways of School and Enterprise Resources Based on Deep Integration, Education and Vocation. 8 ( 2011) 21-23.

[2] L.M. Shi, Analysis and Research of Education Mode of School-enterprise Cooperation, Higher Agricultural Education. 12 ( 2006) 81-84.

[3] J.D. Zhang, The Revelation of Teaching Factory of Singapore to the Construction of Practical Training Base for Vocational Education, Guanli Xuejia. 4 ( 2011) 225.

[4] P.J. Gong, Analyzing the School-enterprise Cooperation Model of Higher Vocational College, Weifang Higher Vocational Education. 7(1) (2011) 45-47.

[5] F.C. Kong, Research on Vocational Education Resources of the School-Enterprise Cooperation from Abroad, Higher Vocational Education: Journal of Tianjin Professional College. 16(2) (2007) 89-92.

[6] L.J. Chen, Exploring the Library and Information Sharing Mechanism of College and Enterprise Which Based on Deep Mix of College and Enterprise: The Investigation for the Requirement of Enterprises in Ningbo Beilun, Journal of Ningbo Polytechnic. 15(3) (2011) 101-105.

[7] H.Y. Li, The Study of Vocational Education Mode of Cooperation between School and Enterprise- Take Weifang Science and Technology Vocational School for Example, Master Thesis, Shandong Normal University, 2008.

[8] D. Gao, M.Z. liu, J. Ji, To Set Up Experimental Teaching Center Featuring Shared Resource between Universities and Enterprises, Research and Exploration in Laboratory. 28(11) (2009) 101-102,111.

[9] Z.C. Wang, G.F. Li, Exploration on the Construction of School-enterprise Resource Sharing Training Base, Education and Vocation. 15 (2011) 45-47.

[10] Y.G. Chen, Research on Educational Pattern of School Enterprises Cooperation and Work Integrated Launched by Higher Vocational Colleges-Take Henan Province for Example, Master Thesis, East China Normal University, 2010.

[11] Y.H. Wang, H.H. Bai, Analysis on Cooperation Patterns between Higher Engineering Vocational Colleges and Enterprises, Journal of Shanxi Vocational \& Technical College. 3(2) (2007) 7-10.

[12] W. Wen, Y.W. Zheng, J.Q. Chen, Analysis of the Education Model of School-enterprise Cooperation about Guizhou Vocation, Journal of Tongren Vocational \& Technical College (Natural Science Edition). 8(5) (2010) 58-62. 